\title{
PANDANGAN DUNIA DALAM SAJAK SEORANG TUA KEPADA ISTRINYA KARYA W.S. RENDRA
}

\author{
Achmad Yuhdi \\ Program Studi Pendidikan Bahasa dan Sastra Indonesia \\ Universitas Negeri Medan \\ e-mail: yuhdiachmad@unimed.ac.id
}

\begin{abstract}
Abstrak
Penelitian ini bertujuan untuk membantu para penikmat puisi W.S Rendra dalam memahami permasalahan sosial dan mengambil pesan moral yang diungkapkan oleh penyair. Puisi yang dianalisis dalam penelitian ini berjudul Sajak Seorang Tua Kepada Istrinya. Metode yang digunakan dalam menganalisis puisi tersebut adalah deskripstif. Analisis dilakukan mengacu teori strukturalisme genetik Lucian Goldman dan teori tentang nilai pendidikan dalam sastra oleh Herman J. Waluyo. Hasil analisis menunjukkan bahwa totalitas pemaknaan "Sajak Seorang Tua Kepada Istrinya" tidak bisa terlepas dari dua unsur pembentuknya/unsur batin. Pandangan/ sikap penyair dalam puisi ini menunjukkan sikap optimisme dan penuh harapan dalam menjalani sisa hidup di hari tua. Penyair mengajarkan kepada pembaca bahwa hari tua dapat begitu menyenangkan bila dimaknai secara benar. Adapun amanat yang ingin disampaikan penyair adalah memberikan motivasi agar sesorang lebih sabar, ikhlas, dan optimistis dalam menghadapi kerasnya kehidupan ini.
\end{abstract}

Kata kunci-nilai pendidikan, puisi, strukturalisme genetik.

\section{A. PENDAHULUAN}

Damono (dalam Escarpit, R, 2005) dalam pengantarnya menyampaikan bahwa dahulu sastra merupakan kristalisasi keyakinan, nilai-nilai, dan norma-norma yang disepakati masyarakat, sedangkan saat ini sastra dapat muncul begitu saja dan pujangga dapat mencipta sastra tanpa peduli apakah masyarakat memilikinya atau tidak. Pandangan ini menegaskan kepada kita bahwa saat ini karya sastra begitu banyak bermunculan tanpa mengedepankan kualitas/nilai sastra yang tinggi. Dengan demikian, perlu dipilah mana saja karya sastra yang memang bernilai mutu sastra yang tinggi melalui kajian-kajian sastra dengan menggunakan teori-teori sastra. Tentu ini merupakan tugas bagi akademisi yang menggeluti bidang bahasa, sastra Indonesia, dan pengajarannya.

W.S. Rendra merupakan salah satu dari sekian banyak penyair yang paling berpengaruh di Indonesia. Rendra dikenal masyarakat luas melalui puisi-puisi yang sifatnya mengkritisi keadaan sosial masyarakat Indonesia, mulai dari kemiskinan, 
penggusuran, ketidakadilan, sampai kepada mengkritisi beberapa kebijakan pemerintah. Salah satu puisinya yang sangat terkenal adalah Sajak Sebatang Lisong (1976) yang pada saat itu mampu membangkitkan semangat dan amarah mahasiswa/pemuda untuk selanjutnya turun ke jalan meneriakkan keadilan.

Puisi-puisi Rendra pun kemudian banyak dianalisis oleh akademisi sastra di perguruan tinggi. Kamagi (2015) meneliti Antologi Puisi Blues untuk Bonnie. Penelitian dilakukannya untuk mendeskripsikan nilai humaniora dalam puisi-puisi dalam buku kumpulan puisi tersebut. Hermoyo (2015) juga melakukan penelitian terhadap puisi Rendra melalui pendekatan strukturalisme genetik. Puisi yang dianalisis adalah Surat Kepada Bunda Tentang Calon Menantunya. Salamah (2019) mengungkap gagasan Rendra tentang system pendidikan Indonesia yang termuat dalam puisi-puisi Rendra. Tentu masih banyak hasil pengkajian terhadap puisi-puisi Rendra yang menarik untuk disimak dan dicermati seksama.

Pemaknaan terhadap karya sastra perlu dilakukan komprehensif melalui penelitian-penelitian yang dipublikasikan pada majalah ilmiah sebagaimana yang disebutkan di atas. Hal ini dikarenakan masyarakat sebagai salah satu unsur penikmat sastra kurang memahami proses pembentukan dan pesan yang ingin disampaikan lewat karya sastra itu. Keberartian penikmatan hanya sebatas mencari hiburan semata, bukan penikmatan sastra sebagai filosofi ataupun sebagai wadah keilmuan. Hal ini dilatarbelakangi masih kurang populernya majalah ilmiah/jurnal sastra yang diterbitkan oleh Perguruan Tinggi yang mengelola jurusan Bahasa dan Sastra Indonesia di kalangan masyarakat penikmat sastra. Masyarakat awan lebih mengenal sastra lewat media elektronik daripada media baca.

Apabila permasalahan tersebut tidak teratasi dengan baik, akan berdampak pada rendahnya motivasi dan minat masyarakat/pembaca untuk menikmati karya sastra. Buku-buku bernilai sastra hanya sebagai pelengkap bahan dagangan pada toko-toko buku atau sebagai bahan pajangan di rak-rak buku perpustakaan. Lebih memprihatinkan lagi, karya sastra akan ditinggalkan oleh pembacanya.

Puisi, sebagai salah satu bentuk sastra, memiliki bentuk dan sifat yang unik. Bentuknya lebih singkat, efektif, dan padat dibandingkan karya prosa atau drama. Penyampaian gagasan dalam bentuk imajinasi dan ilusi digambarkan lewat permainan kata-kata yang mampu menimbulkan efek estetik luar biasa. Peranan bahasa menjadi 
sangat penting dalam proses menciptakan puisi. Memahami sebuah puisi lebih sulit dibandingkan memahami bentuk prosa dan drama karena proses pemaknaannya lebih menonjolkan aspek diksi, baris, dan bait.

Puisi karya W.S. Rendra yang dianalisis dalam penelitian sederhana ini adalah Sajak Seorang Tua Kepada Istrinya. Puisi ini ditulis Rendra pada tahun 1972. Puisi ini sangat popular di dunia maya melalui video pembacaan puisi ini oleh Rendra dan oleh penyair lainnya di media sosial youtube. Dalam tulisan ini, puisi tersebut dianalisis melalui pendekatan strukturalisme genetik. Dengan pendekatan itu, pengkajian karya sastra tidak hanya dilakukan dengan mengkaji unsur intrinsik dan ekstrinsiknya saja, melainkan mengkaji karya sastra dengan menyertakan latar belakang sosial pada saat karya sastra itu dilahirkan karena tidaklah mungkin suatu karya lahir dari suatu kekosongan budaya, dan menyertakan latar belakang pengarang. Karena membicarakan sebuah karya sastra artinya juga membicarakan sastrawan dan gagasannya yang berdiri di belakang karya itu.

Tulisan ini berusaha memberikan pemahaman kepada pembaca/penikmat sastra, meskipun sangat minim, tentang seluk beluk karya sastra, khusunya puisi. Kajian ini diharapkan mampu memberikan gambaran kepada pembaca tentang insur fisik dan batin puisi serta pandangan dunia pengarang terhadap karya sastra yang diciptakannya. Tidak lupa dalam penelitian yang sederhana ini dilakukan juga analisis mengenai nilai-nilai pendidikan yang terkandung dalam puisi karya W.S. Rendra tersebut.

\section{B. KAJIAN TEORI}

\section{Unsur Pembangun Puisi}

Puisi merupakan karya sastra yang paling tua usianya dibandingkan bentuk karya sastra lainnya. Menurut Waluyo (2002:1) "Puisi adalah karya sastra dengan bahasa yang dipadatkan, dipersingkat, dan diberi irama dengan bunyi yang padu dan pemilihan kata-kata kias (imajinatif). Kata-kata itu betul-betul dipilih agar memiliki kekuatan pengucapan". Puisi merupakan bentuk ekspresi seorang pengarang dengan susunan bahasa yang padat dan indah. Definisi atau pengertian puisi menurut Suryaman (2005:20), adalah karya emosi, imajinasi, pemikiran, ide, nada, irama, kesan panca indera, susunan kata, kata-kata kiasan, kepadatan, dan perasaan yang bercampur baur dengan memperhatikan pembaca. Lebih lanjut Pradopo (2002:7), memaknai puisi 
sebagai ekspresi pemikiran yang membangkitkan perasaan, yang merangsang imajinasi panca indra dalam susunan yang berirama.

Sebuah puisi adalah sebuah struktur yang terdiri dari unsur-unsur pembangun. Unsur-unsur tadi dinyatakan bersifat padu karena tidak dapat dipisahkan tampa mengaitkan unsur yang lainnya. Menurut Herman J. Waluyo (2002:17), Adapun unsurunsur yang membangun puisi adalah terdiri dari struktur fisik dan batin.

Struktur batin terdiri dari tema (sense), rasa (feeling), nada (tone), dan amanat. Tema merupakan sentral dari suatu karya dan harus ada. Oleh sebab itu sentral dari suatu karya sastra yang harus ada terlebih dahulu adalah tema. Tema merupakan ide pokok yang menjiwai keseluruhan isi puisi yang mencerminkan persoalan kehidupan manusia, alam dan sekitarnya yang diangkat penyair dari objek seninya. Rasa adalah sifat sang penyair terhadap pokok permasalahan yang ada dalam puisinya. Nada mengungkapkan sikap penyair kepada pembaca atau dengan kata lain di dalam menulis puisi penyair mempunyai sikap tertentu terhadap pembaca. Sedangkan amanat adalah pesan yang igin disampaikan penyair kepada pembaca. Untuk dapat menyimak pesan penyair di dalam puisi maka puisi mestilah dapat ditangkap dan dipahami maknanya secara utuh baik makna yang lugas maupun makna yang utuh.

Struktur fisik ini terdiri dari lima unsur yaitu: diksi, pengimajian, kata konkret, gaya bahasa, dan rima. Diksi (diction) adalah pilihan kata yang dipergunakan oleh penyair dengan demikian cermat dan teliti, bagaimana memiliki kata-kata yang benar mengandung arti yang sesuai dengan maksud puisinya dalam arti denotatif maupun dalam arti konotatif. Pengimajian adalah kata atau susunan kata-kata yang dapat mengungkapkan pengalaman imajinasi. Untuk membangkitkan imaji (daya bayang) pembaca, maka kata-kata harus diperkonkret maksudnya bahwa kata-kata itu harus dapat mengacu kepada arti yang menyeluruh. Seperti halnya pengimajian, kata yang diperkonkret ini juga erat hubungannya dengan penggunaan kiasan atau lambang. Gaya bahasa adalah cara yang dipergunakan oleh penyair untuk membangkitkan dan menciptakan image dengan menggunakan gaya bahasa seperti perbandingan, kiasan, pelambang sehingga makin jelas makna yang hendak dikemukakannya. Rima adalah persamaan bunyi yang terdapat pada kata-kata dalam puisi. Dengan adanya rima itulah, efek bunyi makna yang dikehendaki penyair semakin indah dan makna yang ditimbulkannya pun lebih kuat. 


\section{Pendekatan Strukturalisme Genetik}

Penelitian strukturalisme genetik, memandang karya sastra dari dua sudut yaitu intrinsik dan ekstrinsik. Studi diawali dari kajian unsur intrinsik (kesatuan dan koherensinya) sebagai data dasarnya. Selanjutnya, penelitian akan menghubungkan berbagai unsur dengan realitas masyarakatnya. Karya dipandang sebagai refleksi zaman, yang dapat mengungkapkan aspek sosial, budaya, politik, ekonomi, dan sebagainya. Peristiwa-peristiwa penting dari zamannya akan dihubungkan langsung dengan unsurunsur intrinsik karya sastra.

Lucien Goldman, seorang filsuf dan sosiolog Rumania-Perancis mengemukakan teori strukturalisme genetik yang merupakan awal baru kelahiran pendekatan sosiologi sastra. Strukturalisme genetik dikembangkan atas dasar penolakan terhadap strukturalisme murni, analisis terhadap unsur intrinsik. Strukturalisme genetik hadir dalam rangka menyeimbangkan antara karya sastra dengan aspek di luar karya sastra, yaitu antara hakikat otonomi (unsur intrinsik) dengan hakikat ketergantungan sosialnya. Secara sederhana, strukturalisme genetik dapat dapat diformu-lasikan dalam tiga langkah. Pertama, peneliti bermula dari kajian unsure intrinsik, baik secara parsial maupun dalam jalinan keseluruhan-nya. Kedua, mengkaji kehidupan sosial budaya pengarang, karena ia merupakan bagian dari komunitas tertentu. Ketiga, mengkaji latar belakang sosial dan sejarah yang turut mengkondisikan karya sastra saat diciptakan oleh pengarang (Endraswara, S, 2003: 62). Selanjutnya, Ian Watt (dalam Winarni, R, 2009:167) menjelaskan praktik kajian sastra dapat dimulai dari; a) konteks sosial pengarang, yang mencakup posisi sosial sastrwan dalam masyarakat dan kaitannya dengan pembaca.

Pandangan dunia, bagi Goldmann (dalam Endasrawa, S, 2003: 57) yang selalu terbayang dalam sastra adalah abstraksi (bukan fakta empiris yang memiliki eksistensi obyektif). Abstraksi itu akan mencapai bentuknya yang konkret dalam sastra. Oleh karena pandangan dunia itu suatu bentuk kesadaran kolektif yang mewakili identitas kolektifnya, maka dia secara sahih mewakili kelas sosialnya.

Pandangan dunia pengarang itu sendiri adalah komplek menyeluruh dari gagasangagasan, aspirasi-aspirasi, dan perasaan-perasaan yang menghubungkan secara bersama-sama anggota-anggota suatu kelompok sosial tertentu yang mempertentangkannya dengan kelompok-kelompok sosial yang lain. (Goldmann (dalam Faruk, 2012: 66)). Pandangan dunia yang ditampilkan pengarang lewat tokoh 
problematik (problematic hero) merupakan suatu struktur global yang bermakna. Pandangan dunia ini bukan semata-mata fakta empiris yang bersifat langsung, tetapi merupakan suatu gagasan, aspirasi dan perasaan yang dapat mempersatukan suatu kelompok sosial masyarakat. Pandangan dunia itu memperoleh bentuk konkret di dalam karya sastra. Pandangan dunia bukan fakta. Pandangan dunia tidak memiliki eksistensi objektif, tetapi merupakan ekspresi teoritis dari kondisi dan kepentingan suatu golongan masyarakat tertentu.

\section{METODE PENELITIAN}

Penelitian ini merupakan penelitian deskripsif yang memiliki prosedur penelitian yang lebih menekankan pengkajian analisis berupa uraian tertulis. Pengkajian ini berupaya mendeskripsikan sejelas-jelasnya informasi yang diperoleh, baik melalui proses membaca atau menyimak. Sumber data di dalam penelitian ini yaitu teks puisi yang berjudul Seorang Tua Kepada Istrinya. Sumber data dalam penelitian ini diperoleh dengan analisis dokumen. Peneliti membaca teks puisi kemudian di analisis berdasarkan kajian strukturalisme genetik. Analisis strukturalisme genetik memandang karya sastra dari dua sudut, yaitu instrinsik dan ekstrinsik. Analisis diawali dari kajian unsur instrisik (kesatuan dan koherensinya) sebagi data dasar, kemudian dilanjutkan dengan menghubungkan dengan realitas masyarakatnya.

\section{HASIL DAN PEMBAHASAN}

\section{Struktur Fisik dan Batin Puisi Seorang Tua Kepada Istrinya}

\section{a) Struktur Fisik}

Pada penciptaan puisi "Sajak Seorang Tua Untuk Istrinya" karya W.S. Rendra sering digunakan rima identik. Jenis rima ini banyak menggunkan bentuk perulangan kata. Salah satu bait puisi seperti tersebut meengulang kata "kita" dan "dan" masingmasing tiga kali. Perhatikan bait puisi di bawah ini!

Dan juga masa depan kita yang hampir rampung dan dengan lega akan kita lunaskan

Kita tidaklah sendiri dan terasing dengan nasib kita

Pada aspek ragam bunyi, puisi "Sajak Seorang Tua Untuk Istrinya" tersebut lebih menekankan pada bunyi euphony. Ragam bunyi ini mampu menuansakan suasana 
vitalitas dan gerak. Salah satu ciri bunyi euphony adalah banyaknya kata yang berbunyi vokal. Peranan bunyi pada puisi W.S. Rendra di atas sangatlah besar bagi penciptaan karakter puisi ini. Karakter tersebut tampak pada hampir semua puisi W.S. Rendra yang mencerminkan ciri khas puisi-puisinya. Ragam bunyi dalam Sajak Seorang Tua Untuk Istrinya mampu menciptakan nilai keindahan lewat aspek musikalisasi, menuansakan makna tertentu sebagai perwujudan sikap dan rasa penyairnya, serta mampu menciptakan suasana tertentu sebagai perwujudan suasana batin W.S. Rendra.

Berdasarkan bentuk dan isi, kata dalam puisi dapat dibedakan menjadi: (1) lambang, (2) uttrance/ indice, dan (3) simbol. Lambang adalah kata-kata yang maknanya tidak merujuk pad berbagai macam kemungkinan (makna denotatif). Uttrance/indice adalah kata-kata yang mengandung makna sesuai dengan keberadaan dalam konteks pemakaian. Simbol merupakan kata-kata yang mengandung makna ganda sehingga mmahami makna, pembaca harus menafsirkan secara kontekstual atau parafrasis.

Pendiksian puisi Sajak Seorang Tua Untuk Istrinya tersebut lebih menekankan pada pendiksian lambang. Selain penggunaan kata-kata sederhana dan keseharian, katakata yang dipilih mengandung makna seperti dalam kamus (leksikal). Proses pengimajinasian menyebabkan kata-kata abstrak menjadi konkret dan cermat. Perhatikan penggalan bait berikut ini!

\section{Bukan demi sorga atau neraka}

\section{Tetap demi kehormatan seorang manusia}

Penataan kata dalam puisi sehingga menjadi sesuatu yang lebih bermakna tidak dapat terlepas dari gaya bahasa (style). Kata-kata tidak hanya sekedar diletakkan atau ditempatkan secara sembarangan atau acak tetapi dipilih, ditata, diolah, dan diatur secara cermat. Gaya bahasa yang digunakan dalam puisi "Sajak Seorang Tua Untuk Istrinya" diantaranya anafora. Anafora adalah pengulangan kata atau frase pada dua atau lebih larik puisi secara berurutan.

Sembilan puluh tahun yang dibeli napas kita Sembilan puluh tahun yang selalu bangkit 
Gaya bahasa lain juga ditemukan dalam puisi W.S. Rendra ini adalah personifikasi, yaitu membuat benda mati hidup layaknya manusia atau hewan. Perhatikan bait puisi berikut!

Hidup adalah untuk mengolah hidup

Bekerja membalik tanah,

Memesuki rahasia langit dan samodra

Serta mencipta dan mengukir dunia

Baris dalam puisi pada umumnya merupakan pewadah, penyatu, dan pengemban ide penyair lewat kata. Keberadaan larik-larik puisi tidak dapat kita pisahkan satu dengan yang lainnya. Pertalian makna yang dibangun oleh larik-larik puisi sangat erat. Pada puisi "Sajak Seorang Tua Untuk Istrinya" tersebut terdiri atas 49 baris. Peranan baris dalam pertalian makna sebagai berikut:

Baris $1-12$ : penyair berupaya menghibur istrinya yang dilanda keloyoan di hari tua. Baris 13 - 39 : penyair mencoba memahami kenyataan Baris 40 - 49 : penyair optimis tentang masa depan.

Bait merupakan kestuan larik yang lebih besar yang mengandung satu kesayuan pokok pikiran. Pada puisi "Sajak Seorang Tua Untuk Istrinya" terdiri atas 11 bait. Antarbait membentuk satu kesatuan makna. Contohnya:

Bait $1-3 \quad$ : berupaya menghibur istrinya yang dilanda keloyoan di hari tua.

Bait 4 - 9 : penyair mencoba memahami kenyataan

Bait 10 - 11 : penyair optimis tentang masa depan.

\section{b) Struktur Batin}

Secara implisit, karya sastra merefleksikan proposisi bahwa manusia memiliki sisi kehidupan masa lampau, sekarang, dan masa akan datang. Karena itu, nilai yang terdapat dalam karya sastra tersebut adalah nilai yang hidup dan dianamis (Endraswara, 2011:80).

Kehidupan sosial masyarakat, baik itu secara individual maupun kelompok, dapat menjadi bahan penciptaan suatu puisi. Corak kehidupan masyarakat yang diangkat menjadi bahan penciptaan itu dapat beraneka ragam. Mungkin, berupa adat kebiasaan, pandangan hidup, maupun perilaku suatu masyarakat yang tidak ada hubungannya dengan politik. Perhatikan petikan puisi berikut. 
Aku tulis sajak ini

untuk menghibur hatimu

Sementara kau kenangkan encokmu

kenanglah pada masa remaja kita yang gemilang

Dan juga masa depan kita yang hampir rampung

dan dengan lega akan kita lunaskan

Kita tidaklah sendiri

dan terasing dengan nasib kita

Kerna soalnya adalah hukuman sejarah kehidupan

Suka duka kita bukanlah istimewa

kerna setiap orang mengalaminya

Hidup tidaklah untuk mengeluh dan mengaduh

Setelah membaca penggalan puisi tersebut, tentu akan terbayang bagaimana "aku" W.S. Rendra menempatkan dirinya sebagai "seorang tua" pada keluarganya (istri). Hubungan orang tua dalam berinteraksi dengan orang lain setidaknya mampu memberikan keteduhan hati dan ketegaran jiwa menghadapi segala bentuk tekanan kehidupan. Orang tua, khususnya laki-laki, dalam pandangan penyair harus berupaya memberikan gambaran atau wawasan kepada yang lebih muda tentang permasalahan kehidupan dan bagaimana cara menanggulanginya.

\section{Pandangan Dunia dalam Puisi Seorang Tua Kepada Istrinya}

Pemahaman yang serba sedikit tentang biografi penyair sering berperanan dalam memperlancar pemahaman gagasan yang terdapat dalam puisi yang diciptakannya. W.S.Rendra adalah seorang sosok penyair yang dikenal masyarakat sebagai tokoh yang peduli terhadap kehidupan sosial masyarakat. Kejadian atau peristiwa yang menimpa masyarakat sering dijadikan topik penulisan karyanya. Ketimpangan-ketimpangan sosial, kebobrokan birokrasi penguasa, ketertindasan, dan penzaliman terhadap masyarakat pinggiran dikemas dalam puisi berbau kritikan. Pada akhirnya, karya-karya W.S.Rendra lebih menonjolkan kritik sosial.

Dalam puisi Sajak Seorang Tua Untuk Istrinya, W.S. Rendra tidak begitu menampakkan kritikan untuk orang lain. Tetapi, lebih mengkritisi sikap kehidupannya sendiri. Cerminan sikap ini, setidaknya dapat ditemukan pada penggalan puisi dberikut ini.

Lihatlah! Sembilan puluh tahun penuh warna!

Kenanglah bahwa kita telah selalu menolak menjadi 
koma

Kita menjadi goyah dan bongkok

Kerna usia nampaknya lebih kuat dari kita

tapi bukan kerna kita telah dikalahkan.

Setiap menghadirkan gagasan tertentu, penyair mendasarkan dirinya pada sikap tertentu. W.S. Rendra dalam puisi yang dianalisis ini bersikap sangat peduli menghadapi corak kehidupan masyarakatnya. Kepedulian ini sangat jelas tergambar saat penyair menemukan istri tercintanya galau atau bimbang dalam menghadapi kehidupan saat itu yang penuh beban.

Aku tulis sajak ini untuk menghibur hatimu Sementara kau kenangkan encokmu kenanglah pada masa remaja kita yang gemilang

Selain memiliki kepedulian yang besar terhadap corak kehidupannya, penyair merupakan sosok yang kaya wawasan dan filosofi. Ketegarannya dalam berfilosofi mampu menggugah pandangan pembacanya.

Bukan demi sorga atau neraka

Tetapi demi kehormatan seorang manusia

Karna sesungguhnya kita bukan debu meski kita telah reot, tua renta bukan kelabu Kita adalah kepribadian

Lewat puisi yang ditulisnya, W.S. Rendra ingin memberikan "wejangan" atau pembelajaran bagaimana sikap dan cara pembaca menghadapi kehidupan ini. Kehidupan yang penuh dengan kebimbangan, keraguan, kepesimisan, dan keputusasaan dapat "diredam" dan dibangkitkan melalui refleksi diri. Orang hidup hendaknya sering melongok perjalanan masa lalunya agar ada ketegaran di hati. Pahami penggalan puisi berikut ini!

Lihatlah betapa bertahun-tahun kita penuh warna.

Sembilan puluh tahun yang dibeli dengan napas kita.

Sembilan puluh tahun yang selalu bangkit

melewatkan tahun-tahun lama yang porak poranda

Dan kenanglah pula.

bagaimana kita kita dahulu tersenyum senantiasa

menghadapi langit dan bumi, dan juga nasib kita.

... . 
Penggalan puisi tersebut menggambarkan sikap penyair yang optimis atau penuh keyakinan dalam menghadapi jalan kehidupan. Penyair yakin bahwa kehidupan ini hendaknya dijalani dengan penuh keikhlasan, bukan keterpaksaan. Senang susah dan sedih bahagia pasti akan dialami semua orang.

Dalam puisi ini W.S. Rendra berupaya memberikan gambaran kepada pembaca tentang menumbuhkembangkan sikap sabar, ikhlas, dan optimistis menghadapi kehidupan ini. Penggambaran tersebut dilukiskan dengan pemilihan kata yang sederhana dan tepat. Meskipun lebih banyak bersikap menggurui, penyair yakin bahwa yang disampaikan akan diterima pembacanya.

Hidup adalah untuk mengolah hidup,

bekerja membalik tanah, memesuki rahasia langit dan samodra, serta mencipta dan mengukir dunia.

Kita menyandang tugas,

karena tugas untuk tugas

Sebagai salah satu bagian karya sastra, karya puisi, selain mengandung nilai-nilai kehidupan, juga mengandung nilai kesejarahan. Nilai-nilai kehidupan tidak bisa terlepas dari budaya masyarakat yang ada. Budaya masyarakat yang dimaksud dalam kaitan ini adalah nilai-nilai dan tindakan berpola dari manusia masyarakat. Dalam puisi ini W.S. Rendra berupaya mengingatkan pembaca tentang pentingnya budaya peduli, budaya ikhlas, dan budaya sabar menghadapi kerasnya kehidupan ini. Peduli, ikhlas, dan sabar memang berupa sikap, tetapi bila dilakukan secara berkesinambungan dan berpola akan mampu menjadi budaya. Hal inilah yang dicita-citakan W.S. Rendra dalam puisinya ini.

\section{E. SIMPULAN}

Berdasarkan hasil penelitian terhadap pengkajian puisi Seorang Tua Kepada Istrinya dapat disimpulkan bahwa puisi ini memiliki kesatuan unsur fisik dan unsur batin. Unsur fisik yang terdapat dalam puisi ini membuat puisi ini menjadi menarik secara tampilan dan bernas serta lugas dari aspek diksi dan gaya bahasa. Dilihat dari unsur batin puisi ini menyampaikan pesan kepada pembaca agar tidak merasa sedih di saat menjalani hari tua dengan menyesali perihal yang dikerjakan di waktu muda. Pandangan dunia dalam puisi ini menunjukkan pembentukan sikap orang lain atau keluarga dalam lingkungannya, saat ini mengalami pergeseran nilai. Penyair berusaha 
memberikan gambaran ketulusan dan keikhlasan untuk peduli kepada orang lain. Bagaimana penyair memberikan gambaran tentang perlunya wawasan dan filosofi yang luas untuk menghadapi tantangan kehidupan yang merupakan cita-citanya dalam menuliskan puisi ini.

\section{F. SARAN}

Berdasarkan hasil penelitian ini, penulis memberikan saran kepada pembaca/penikmat sastra agar setelah membaca karya sastra, juga membaca analisis yang sudah dipublikasikan dalam berbagai jurnal ilmiah terhadap karya sastra itu. Hal ini berguna untuk memaknai karya sastra secara komprehensif. Kepada peneliti selanjutnya, disarankan untuk terus menggali makna yang tersirat dalam karya sastra yang ditulis oleh sastrawan Indonesia.

\section{G. DAFTAR PUSTAKA}

Endraswara, S. (2003). Metodologi Penelitian Sastra. Yogyakarta: Pustaka Widyatama.

Escarpit, R. (2005). Sosiologi Sastra; penerjemah, Ida Sundari Husein-Ed-1. Jakarta: Yayasan Obor Indonesia.

Faruk. (2012). Pengantar Sosiologi Sastra. Yogyakarta: Pustaka Pelajar.

Hermoyo, R. Panji. (2015). Analisis Kritik Sastra Puisi Surat Kepada Bunda Tentang Calon Menantunya. DIDAKTIS: Jurnal Pendidikan dan Ilmu Pengetahuan. 15 (1) hal 44-53. DOI: http://dx.doi.org/10.30651/didaktis.v15i1.40

Jabrohim (ed). (2012). Teori Penelitian Sastra. Yogyakarta: Pustaka Pelajar.

Kamagi, L. (2015). Nilai-nilai humaniora dalam antologi puisi "Blues untuk Bonnie" Karya WS Rendra. BAHTERA: Jurnal Pendidikan Bahasa dan Sastra. 14 (1) hal 26-38. DOI: https://doi.org/10.21009/BAHTERA.141.03.

Pradopo, R. D. (1997). Pengkajian Puisi. Yogyakarta: Gadjah Mada University Press.

Salamah, Umi. (2019). Gagasan W.S. Rendra Tentang Sistem Pendidikan Indonesia: Resistensi Terhadap Sistem Pendidikan Kekuasaan Orde Baru. ALFABETA: Jurnal Bahasa, Sastra, dan Pembelajarannya. 2 (1) hal 20-40. DOI: https://doi.org/10.33503/alfabeta.v2i1.462.

Suryaman, dkk. (2005). Kajian Puisi. Yogyakarta: UNY.

Waluyo, Herman J. 2002. Apresiasi Puisi. Jakarta: Gramedia Pustaka Utama. . (2011). Pengkajian dan Apresiasi Prosa Fiksi. Surakarta: UPT UNS Press. 